BMC JOURNAL OF SCIENTIFIC RESEARCH

A Multidisciplinary Research Journal

ISSN: 2594-3421

\title{
Alienation and Double Consciousness in Jhumpa Lahiri’s Short Story "When Mr. Pirzada Came to Dine"
}

\author{
Dharma Thapa* \\ dhrm.thp@gmail.com
}

\begin{abstract}
Decolonisation and globalisation have given tremendous impetus to the shift and mobility of people from the former colonies and semi colonies to the metropolitan locations. This has brought about big changes in how they live, how they think and what they experience. Designated as diaspora, this kind of living has offered some opportunities and at the same time posed multiple challenges and problems. In this article, an attempt has been made to analyse Jhumpa Lahiri's short story "When Mr. Pirzada Came to Dine" from the angle of how such diasporic living is problematic and full of tension and the characters 'psyche is drawn towards two conflicting cultural locations- the original and the cosmopolitan. The focus of the analysis is Mr. Pirzada, the central figure of the story. As the representation of this kind duality of living in literature is studied under the rubric known as Post Colonialism, I have used the theoretical views of the post colonial scholars like Arjun Appadhurai, Radhakrishnan Rajgopalan and others as conceptual tools for this purpose.
\end{abstract}

Key Words: Diaspora, Alienation, Double Consciousness, Cultural Loss

\section{Introduction}

"When Mr. Pirzada Came to Dine" is one of the nine stories anthologized in Inerpreter of Maladies, a collection of short stories by Jhumpa Lahiri. All of the stories in this collection represent diverse aspects of diasporic living of South Asian characters in America. However, this brief article focuses the particular story "When Mr. Pirzada Came to Dine" to see how the diasporic living is not always promising and the immigrants' psyche is gripped by the sense of alienation and double consciousness. The story relates the predicament of four main characters: Lilia, her parents and Mr. Pirzada. Mr. Pirzada comes from East Pakistan which is in the process of becoming Bangladesh. He has been there to study the foliage of New England. Lilia's parents have come from India and work at a campus. For these characters the U S is culturally and spatially a new and unfamiliar space and feel home sick and persistently long for their original place. As a form of compensation, according to Lilia, her parents trailing their fingers through the columns of the university directory in search of compatriots and keep inviting to dinner if found any. Mr. Pirzada keeps two watches one of which he sets to the Dacca time. Her parents hold contradictory attitudes to the things American and Indian. She herself is drawn to India despite being born and brought up in the American culture. In this article I have shown how these characters and their attitudes, the events, the setting and images function as metaphors for the condition of alienation and double consciousness as a part and consequence of diasporic * Mr. Thapa is Reader in English at Birendra Multiple Campus (Tribhuvan University) 
living. I also demonstrate how this condition is related with postcolonial and post national issues. For this purpose I will be using the theoretical concepts developed by the writers like Arjun Appadurai, Radhakrishnan, Jana Evans Braziel, Anita Mannur and others.

\section{Duality of Living: a Post Colonial Perspective}

In Radhakrishnan Rajgopalan's view diasporic existence is a very complex phenomenon. Throwing light on this side of the problem he states:

...diasporas that have found a home away from home in the very heartland of former colonialism. And this home away from home is full of lies and duplicities. A diasporic citizen may very likely find economic betterment in the new home, but this very often is allied with a sense of political-cultural loss. If the diasporic self is forever marked by a double consciousness, then its entry as legitimate citizen into the adopted home is also necessarily double. (Rajgopalan, 1996, p.174)

His opinion makes at least four things clear about diasporic condition: one is that it is a "home away from home" which is set in the "very heartland of former colonialism." The characters under consideration have found "a home" in America although Mr. Pirzada does not qualify this criterion because his stay in America is temporary. Regarding the "the heartland of former colonialism" the United States of America may not be the literal location of former imperial power which colonized the Indian subcontinent. Nonetheless, due to the shift in the balance of power after the Second World War, the U S has inherited the British imperial legacy and has become the global metropolis of the present day world and also the main destination of those who think they could find opportunity for their career development. Secondly, these subjects aim at "economic betterment." Mr. Pirzada and Lilia's family have come to America for academic advancement which is ultimately related to economic opportunities and betterment. The third point is that these people are at political- cultural "loss". Fourthly, they are always guided by the sense of double consciousness which is the main concern of this paper. By double consciousness what is meant is the divided psychological condition of the character/s due to the existence drawn to two cultural locations simultaneously. This kind of situation appears in the story because major characters like Mr. Pirzada and Lilia's parents live in the U $\mathrm{S}$ as immigrants. As they live in the U S, they have to learn the American way of life. At the same time they are constantly haunted by the memory of their former home land. In the same essay Radha Krishnan also talks about the American context in which the diasporic existence is marked by "pain and alienation." In fact the sense of "pain and alienation" is the outcome of living through double consciousness by immigrants.

In his essay "Disjuncture and Difference in the Global Cultural Economy" Arjun Appadurai proposes framework in which he discusses five "dimensions of global cultural flow" one of which is "ethnoscapes" ( Appadurai, 2003, p.31). By ethnoscape he means "the landscape of persons who constitute the shifting world in which we live: tourists, immigrants, refugees, exiles, guest workers . . . to affect the politics of (and in between) nations to a hitherto unprecedented 
degree" (p.32). Unlike Radhakrishnan Appadurai's attitude to global flow and interaction of people and things is celebratory. However, his five dimensional flow of culture is useful to understand the present day world in which globalization of people and culture has become a growingly dominant mode of living. These days the world has turned into a single global market of culture, goods, ideologies, physical or intellectual human beings in which, along with other elements, the demand and supply of the man power is also global. This kind of situation has made the life of double consciousness inevitable which involves both- pleasure and pain. The four characters under discussion are the product of the flow of "ethnoscapes" in the context of globalisation as suggested by Appadurai and the ambition for the betterment of the formerly colonised people by migrating to the global metropolis as suggested by Radhakrishnan. Each of the characters shares the same pain of alienation, double consciousness, nostalgia and sense of loss in varying the magnitude and intensity.

According to Lilia, the narrator of the story, Mr. Pirzada is in America to study the foliage of New England on a "grant from the government of Pakistan" (Lahiri, 2010, p.24). He lived in a room in a graduate dormitory which is poor in terms of physical facilities. But along with the study, he is caught up in the foliage of the human relationship, and the sense of cultural loss, memory and nostalgia. He finds it more entangling than the spring and summer time foliage of Vermont and Maine (p.25). Although his stay in America is for a limited period of time, he is very much haunted by sense of alienation and the memory of his family and the home country which is itself in the state of uncertainty, conflict and the battle ground of international power politics. He finds himself in an awkward position to adopt in the unfamiliar society, culture and physical environment. He resorts to the native sense of time and space for relief and compensation. According to Lilia:

Before eating Mr. Pirzada did a curious thing. He took out a plain silver watch without a band, which he kept in his breast pocket, held it briefly to one of his tufted ears, and wound it with three swift flicks of his thumb and forefinger. Unlike the watch on his wrist, the pocket watch, he had explained to me, was set to the local time in Dacca, eleven hours ahead. (Lahari, 2010, p.30)

Here the use of two watches side by side is an attempt on the part of Mr. Pirzada to cope with the duality of time consciousness and also to mitigate the stress of alienation. On the one hand, in his physical living, he has to keep pace with the American sense of time which is very sharp and fast. Failure to keep pace with it means failure in one's career. On the other, he psychologically and in the form of memory he has to remind himself of his native time and its pace. Winding the silver watch time, he keeps himself in tune with the Dacca time. In fact Lilia herself remarks that she realized "life was being lived in Dacca first" (p.30). She further concludes that the meals in her home, the actions, were only a shadow of what had already happened there in Decca. Everything in America is "a lagging ghost of where Mr. Pirzada really belonged" (p.31). 
Pirzada is the most alienated of the four characters. Though he is living there for a relatively short time, he is cut off from his family, the country and its physical as well as social environment. His identity as a citizen belonging to a particular nation state is also in the process of change because of the division of the country. From a Pakistani, he is going to be metamorphosed into a Bangladeshi citizen. His sense of double consciousness and alienation is further aggravated by this traumatic event and his inability to understand and cope up with the American culture, mannerisms and etiquettes. Every time he visits the narrator, he gives her candy. But she does not thank him knowing that he has an aversion to it. She quotes him saying “... the librarian thanks me when I return an overdue book; the overseas operator thanks me as she tries to connect me to Decca and fails. If I am buried in this country, I will be thanked, no doubt, at my funeral" (p.29).

This is the most trying situation for him because to become adapt to the unfamiliar people and their mannerism, especially for his being from the periphery of the globe. Americans are not required to adopt and understand his etiquettes not only for the fact that he is in their place but also because he comes from the location which they take as the inferior other. In other words he has to adopt the American values and change himself according to their standard, not the other way round. Despite every effort, he will permanently remain the "other" in the U. S. He has to qualify his remarks which show how lack of understanding of any cultural practices aggravates one's foreignness and alienation. In the South Asian context, for example, the context for thanking somebody means that the speaker is really grateful to the other person. But in the West it is merely a practice of formality, the point he comes to realize very late.

In the story there is another place where Mr. Pirzada's failure to adapt himself to the American culture becomes evident. In his attempt to please Lilia he tries to make a jack-o'-lantern out of a purchased pumpkin for Halloween which is a totally different cultural practice for a non Westerner like Pirzada. While working with it his knife slips from his hand and makes a gash dipping toward the pumpkin. This results in a "large hole the size of a lemon, so that ... wore an expression of placid astonishment, the eyebrows no longer fierce, floating in frozen surprise above a vacant, geometric gaze" (p.36). Here the astonished, floating, and vacant gaze of the jack-o'-lantern is the metaphor for the astonished and confused existence of Mr. Pirzada himself. In fact the pumpkin episode stands for the failure of Mr. Pirzada's and Lilia's parents' attempt to adapt themselves to the U S culture. Metaphorically and literally, this indicates cultural incompatibility of them. By buying a pumpkin for Halloween they have attempted to buy the adaptability which, as I have already stressed, turns out to be a failure except for Lilia. The case of Lilia's parents is a lot more different. Unlike Mr. Pirzada they have found a permanent home there and they do not have to face the pain of the separation of the family members. However, this does not save them from having to feel the pain of the situation of alienation and double consciousness. Their condition is like what Jana Evans Braziel and Anita Mannur have commented explaining Appadurai's concept of global culture as "loosely associated with other terms; particularly transnationalism, to describe the disjunctures and fractured condition of late modernity" ( emphasis mine, Braziel and Mannur, 2003, p.3). 
The disjunctures and fractured mentality can be found in their incessant search of compatriots and invitation to dinner despite the high cost for it because of the expensive and individualistic American society. It is one of these searches that they have discovered Mr. Pirzada. Although he belongs to East Pakistan, traditionally a hostile country for the Indians, he is treated as a treasured object in the family. This measures the intensity of their nostalgia for India and its surroundings. The things that bring them closer are common cultural heritage and even food habits. Lilia finds this commonality:

Mr. Pirzada and my parents spoke the same language, laughed at the same jokes, looked more or less the same. They ate pickled mangoes with their meals, ate rice every night for supper with their hands. Like my parents, Mr. Pirzada took off his shoes before entering a room, chewed fennel seeds after meal as digestive, drank no alcohol, for dessert dipped austere biscuits into successive cups of tea... (p.25)

Here Lilia's distancing herself from her parents and Mr. Pirzada is noticeable which I will discuss later. Here what I want to show with this quotation is that her parents' fondness for him is grounded on their nostalgia for their former home which is aggravated by the sense of their being cut off from the root. This strongly demonstrates their transnationalism, disjuncture and fractured condition. This is, to use the words of Jana Evans Braziel and Anita Mannur, Janus like situation "whose gaze is simultaneously directed both forward and backward" (p.9). This means that they have longing for the past which is rooted in the former country and also they have to adapt to the present culture and country. This is exactly what hybridity and transnationalism means.

The sense of alienation especially of Mr. Pirzada and the parents comes from multiple sources. It does not simply come from the characters' selves being divided into the past and present and here and there. It has already crept in their family. This can be seen in the contrary attitudes of the father and the mother regarding the matters the Indian sub continent. In fact the family itself has turned into a miniature India and America through the discussion and $\mathrm{T} V$ news on the pertinent topics. The father and Mr. Pirzada get never tired of talking about the Indian history before and after the partition. Contrary to this, the mother does not want them to talk about the Indian past so often. She feels proud of the America for its "a safe life, an easy life, a fine education, every opportunity" (p.26). She takes the Indian past as "rationed food," "curfews," "riots" and "bullet"shots (p.26). If her husband is primarily oriented to the memory of the former location, her orientation is to the present and the future. In this sense she is close to Lilia who maintains a generational distance with her parents. The differences between the husband and wife make alienation more acute and pervasive leaving chances open for further fragmentation in the family itself.

Quite a few numbers of scholars have looked into the issues and problems migrants from various angels. The fashionable academic rubric is known as Post Colonialism. One of the 
ways is to focus on the customs and cultures with which they arrive in the new location. John McLeod has tried to pinpoint this kind of situation. He opines:

In migrating from one country to another, migrants inevitably become involved in the process of setting up home in a new land. This can also add to the ways in which the concept of home is disturbed. Migrants tend to arrive in new places with baggage; both in the physical sense of possessions or belongings, but also the less tangible matter of beliefs, traditions, customs, behaviours and values. (emphasis added, McLeod, 2010, p.211)

Here my present concern is not the tangible belongings of the migrants but, as I have discussed earlier, it is the less tangible matters like beliefs, traditions, customs and values that matter more because these less tangible things influence the way the migrants live. It is these values that force not only the India born characters like Mr. Pirzada and Lilia's parents to live in the condition of alienation and double consciousness ,more or less it forces America born character like Lilia herself to live through the same condition because culture is something which is assimilated into the blood or psyche of the person.

When the story starts (in the autumn of 1979), Lilia is ten. Although she is much more attuned to American life style, she too cannot help feeling the duality of the culture. In fact her attempt to cut off herself from the Indian past fails. One of her most treasured asset is "a small keepsake box made of carved sandalwood" which long ago her grandmother used and which she now uses to keep the candy given Mr. Pirzada (p.22). This memento symbolizes her connectedness with the ancestral homeland. While talking about the activities of Mr. Pirzada and her parents, she excludes herself from their collectivity by using the distancing word "they." Instead of saying "We ate...," she says "They ate pickled mangoes," "They talked" etc. This is her conscious attempt to avoid the legacy of her parents. In one place she describes the partition of India in terms of the American political map. She successfully accomplishes the ritual of Halloween trick with her colleagues. This demonstrates the extent of her Americanization. Despite being largely assimilated and acculturated in the American society, she is forced to be drawn to the Indian past. In fact she has to live through two cultures simultaneously. At home Indian atmosphere dominates. They watch news about India, Pakistan and Bangladesh on $\mathrm{T}$ V. They eat Indian food and receive Indian or sub continental guests like Mr. Pirzada. They listened to songs by the popular Indian singer Kishore Kumar. In this atmosphere she cannot be indifferent to the tangible and intangible materials related to India. At school the environment is totally different. There she goes through American ways of doing things. She learns American history and American geography. The school takes her on trips to the places like Plymouth Rock, the Freedom Trail the top of the Bunker Hill Monument and many others. In the library Mrs. Kenyon, the instructor, forces her to read the book on the American history while she secretly reads a book on the history of Pakistan. 
This way we find the characters in "When Mr. Pirzada Came to Dine," despite generational differences, are drawn toward to the past and the present cultural locations and passing through the experiences of alienation and double consciousness. However, this does not mean that they all go through the same amount of alienation. As I have already stressed, the cultural gap among them is not insignificant. The possibility of alienation and double consciousness, for example, in the family of Lilia itself exists substantially. This can result in a painful situation for it largely due to the generation gap between Lilia herself and her parents, more specifically her father, because in her the sense of present is very dominating over her understanding of the Indian past. Unlike the parents, who have first hand experience of India and its cultural climate, her knowledge about is second hand and not direct and personal. They come to her through secondary sources like the accounts of the parents, the media and history books. So this difference leads to the situation in which the parents' memory of the past either remains constant or becomes more obsessive and her concern is sure to become mere referential. This is what can be said an inevitable by-product of diasporic settlement.

As Jana Evans Braziel and Anita Mannur have outlined the mass migrations and displacements of the second half of the twentieth century is related with the independence movement in formerly colonized areas (2003, p.4). This means that the transnational flow of people is a postcolonial phenomenon. To borrow Appadurai's concept it is the result of multiple flow of people, capital, technology, media and ideology in the decolonized and globalized world which has become somehow open to the formerly colonized people. It is true that the advanced technology and the subsequent mobility of people across the globe have offered a lot of opportunities and challenges to those who have sufficient money, talent and energy. On the other hand the imperialists or neo colonialists have learnt from experience that it is useful for them to bribe the most talented strata of the former colonies so that they can divert the intelligentsia from the possible resistance movement and they can continue the plunder of the third world countries in an advanced form. The upper middle class people water their mouths for the bourgeois western life style. They feel that there is not only loss and risk in the self exiled living; there are also gains and rewards in terms of income and prestige before the people of the former location. As these two points meet we have the people like in Jhumpa Lahiri's story. But things do not move as smoothly as expected. There may not be financial problems for these immigrants as long as imperialists can dominate the world. But they are sure to face unforeseen sufferings and psychological problems like loss of identity, nostalgia, discrimination, alienation and many others. This is exactly what Radha Krishnan means when he talks about "a sense of politicalcultural loss" and "pain and alienation" of the metropolitan diasporas.

\section{Conclusion}

To conclude, Jhumpa Lahiri's short story "When Mr. Pirzada Came to Dine" very faithfully presents the diasporic experience in the metropolitan location which is marked by, despite relative secure financial position, multiple alienation and double consciousness. On the one hand we have the characters drawn to the original country, with strong nostalgia for it and on 
the other; they have to cope with the challenges of the new location. The characters themselves are pulled to these two opposite cultural poles differently, worsening the condition of alienation. The differing positions of Lilia, her father and her mother regarding Indian and American cultures demonstrate this. The story also shows this type of physical movement of people from the less developed parts of the globe to the metropolitan locations, despite advantages and opportunities, usually results in psychological loss, trauma, memory and anxiety which are the inseparable by-products of globalization and postcolonial situation.

\section{References}

Appadurai, Arjun. (2003). "Disjuncture and Difference in the Global Cultural Economy." Theorizing Diaspora. Eds. Jana Evans Braziel and Anita Mannur. Malden: Blackwell Publishing, 25-45.

Braziel, Jana Evans and Anita Mannur. (2003). "Nation, Migration, Globalization: Points of contention in Diaspora Studies." Theorizing Diaspora. Eds. Jana Evans Braziel and Anita Mannur. Malden: Blackwell Publishing 1-12.

Lahiri, Jhumpa. (2010). “When Mr. Pirzada Came to Dine.” Interpreter of Maladies. Harper Collins Publishers India, 21-42.

Mc Leod, John. (2010).Beginning Postcolonialism. New Delhi: Viva Books Radhakrishnan, Rajgopalan. (1996). Postcoloniality and the Boundaries of Identity.” Diasporic Meditations:Between Home and Location. University of Minnesota Press, 155-184. 